The CIA and the Culture of Failure 



\section{The CIA and the Culture of Failure}

U.S. INTELLIGENCE

FROM THE END OF THE COLD WAR

TO THE INVASION OF IRAQ

John Diamond 
Stanford University Press

Stanford, California

(C)2008 by the Board of Trustees of the Leland Stanford Junior University.

All rights reserved.

No part of this book may be reproduced or transmitted in any form or by any means, electronic or mechanical, including photocopying and recording, or in any information storage or retrieval system without the prior written permission of Stanford University Press.

Printed in the United States of America on acid-free, archival-quality paper

Library of Congress Cataloging-in-Publication Data

Diamond, John (John M.)

The CIA and the culture of failure : U.S. intelligence from the end of the Cold War to the invasion of Iraq / John Diamond.

p. $\mathrm{cm}$.

Includes bibliographical references and index.

ISBN 978-0-8047-5601-3 (cloth : alk. paper)

1. United States. Central Intelligence Agency-History. 2. Intelligence service-United States-History. I. Title.

JK468.I6D53 2008

$327.1273009^{\prime} 049-\mathrm{dc} 22$

2008011826

Typeset by Bruce Lundquist in in 10/14 Minion

Special discounts for bulk quantities of Stanford Security Series are available to corporations, professional associations, and other organizations. For details and discount information, contact the special sales department of Stanford University Press.

Tel: (650) 736-1783, Fax: (650) 736-1784 
To Celia 
